\title{
Tanzanian EFL Teachers' Perceptions and Attitudes towards Communicative Language Teaching (CLT): A Case Study of Secondary Schools in Morogoro Municipality, Tanzania
}

\author{
Emmanuel S. Ndulila ${ }^{1}$, Erasmus Akiley Msuya ${ }^{2}$ \\ ${ }^{I}$ Communication Skills Unit, Mineral Resources Institute, Dodoma Municipality, Tanzania \\ ${ }^{2}$ Department of Foreign Languages and Linguistics, University of Dar es Salaam
}

*Corresponding Author: Emmanuel S. Ndulila, Morogoro Secondary School, Morogoro Municipality, Tanzania

\begin{abstract}
The current study sought to investigate the Tanzanian EFL teachers' attitudes towards Communicative Language Teaching (CLT) approach. The study was specifically meant to explore teachers' attitudes towards the practice and to establish the extent to which EFL teachers' preferred classroom language T/L activities comply with CLT.

The study relied on the data from teachers in Morogoro Municipality and it aimed at examining their perceptions and attitudes towards CLT. The study used a case study design and it involved ten (10) teachers from five (5) secondary schools in Morogoro Municipality. The study employed Dunkin and Biddle's (1974) model as a theoretical framework.

Data were gathered through attitudinal questionnaire. The findings revealed that most teachers had positive attitudes and perceptions towards CLT. However, their perceptions and attitudes were not congruent with their pedagogical behaviours shown in their language classrooms.

It is concluded that the fact that teachers claiming to be followers of CLT while relying on traditional methods of language teaching and learning needs immediate intervention to curb the situation for proper, effective and efficient implementation of the approach. It is recommended that the government review its English teachers' training curriculum so as to ensure that teachers are well prepared, equipped with relevant knowledge and skills to enable them to effectively implement CLT.
\end{abstract}

Keywords: CLT, Attitude, Perception, Teachers

\section{INTRODUCTION}

Since 1970s, Second Language (SL) and Foreign Language educators have embraced Communicative Language Teaching (CLT) as an alternative to traditional methods i.e. Audio Lingua (AL) and Grammar Translation (GT). AL and GT as old methods embrace the theory of behaviourism whose belief is that language learning is a process of acquiring verbal habits by imitating and repeating good habits (Nunan, 2004).

Unlike AL and GT, the fundamental goal of CLT is to develop learners' communicative competence in L2 or FL. The goal is achieved through communication and interaction among the learners themselves and the teacher as their facilitator. CLT requires learners of the target language to be competent in four aspects of language: linguistic competence, sociolinguistic competence, discourse competence and strategic competence of which these competences were not reinforced by AL and GT methods.

In Asia for example according to Samimy and Kombayashi (2004) as cited in McClintock (2012), the National Ministry of Education, Science and Culture of Japan introduced CLT into their curriculum in 1980s. South Korea began to implement the approach in their $6^{\text {th }}$ and the $7^{\text {th }}$ revised curriculum in 1997. In China, according to Zhu (2003) official implementation of CLT approach began in 1990s in addition to many other countries in Asia. Similarly, many African countries began to implement CLT approach in late 1980s, but most of them began officially in early 1990s. Zimbabwe, as Abd AlMagid (2006) asserts, began to officially introduce CLT in 1992 similar to Lesotho and South Africa. 
In Tanzania, according to Kipacha (1993), CLT was introduced in 1990s although its official implementation was not started until 2005 when the country made major changes in the secondary school curriculum to embrace what is called Competence Based Education (CBE) system (Dominician, 2008). Competence Based Education System was introduced for the purpose of empowering Tanzanian learners to develop knowledge and skills that would enable them to demonstrate performance.

Since introduction of the new curriculum in Tanzania in 2005, the focus of teaching and learning of English changed from empowering learners master grammatical competence to guiding them acquire communicative competence. Learners are empowered to utilize linguistic, pragmatic, discourse and strategic competences when communicating in English.

Despite the changes, many secondary school students and university graduates lack skills and effective communication in English, as Mohamed (2006) and Msuya (2011) assert. Secondary school students and graduates are unable to write even a single comprehensible passage in English. Apart from that, lecture method and other forms of traditional language teaching and learning still persist and dominate in the current teachers' communicative language classrooms.

Therefore, this study sought to examine Tanzanian EFL teachers' perceptions and attitudes towards CLT. Teachers' perceptions and attitudes were ascertained by analysis of their views and opinions to determine how their perceptions and attitudes.

\section{LITERATURE REVIEW}

\subsection{The Notion of Communicative Approach (CA)}

Communicative Approach is a revolutionary approach which shifts attention of language teaching and learning from language competence to communicative competence. Communicative Language Teaching (CLT) originated from Europe in 1960s to early 1970s. The approach later spread to other parts of the world. The new approach was developed against teaching strategies and techniques which put emphases on 'drill' and other forms of rote learning. According to Nunan (2004), this was a paradigm shift from behaviourist psychology to socio-cognitive psychology or constructivist theory of language teaching which the new approach is based on a more contextualized meaning-based view of language.

The proponents of CLT approach contend that the approach aims at making communicative competence as a goal of language teaching and to develop procedures for the teaching of four language skills. According to this approach, teaching and learning are for communication purposes. It presupposes that language always occurs in a social context and it should not be divorced from its context when it is being taught.

This paradigm shift rooted from the belief that language learning is not merely 'knowing that' (declarative knowledge) but rather 'knowing how' (procedural knowledge). According to Kobo (2013), CLT is an approach which develops procedures for teaching skills of language that make communication possible. In general, CLT rests on the notion that language is a tool for communication rather than sets of phonological, grammatical and lexical items to be memorized. Thus, with CLT, learners are equipped with strategies that enable them to communicate effectively in real-life situations.

\subsection{Previous Related Studies on Communicative Approach}

\section{a) In Europe and Asia}

In Europe and North America, CLT approach has been so successful compared to other countries (Savignon, 2000). Ansarey (2012) asserts that despite the growing popularity of CLT in most ESL and EFL countries, there have been many challenges pertaining to the implementation of CLT approach. Nakata (1990), as cited in McClintock (2012), reports that, in Japan, CLT has been shown to be difficult to implement in many facets of education system. The study reports that the difficulties exist in syllabus design, communicative competence of Japanese teachers, and the standardized testing system. 
Tanzanian EFL Teachers' Perceptions and Attitudes towards Communicative Language Teaching (CLT): A Case Study of Secondary Schools in Morogoro Municipality, Tanzania

Ellis (1994) in McClintock (ibid) reports that one of the main problems in using CLT approach in Vietnam was the teachers' continued dependence on the traditional teaching practices and observes that, despite the fact that language curriculum in Vietnam embraces CLT teachers are in favour of the traditional styles of teaching due to the problem of class size and English proficiency of Vietnam teachers.

In Greece, a study by Koravas-Doukas (1996) on teachers' attitudes towards the use of communicative approach revealed that, although the Greece English curriculum is based on the premises of CLT, teachers showed a tendency to carry on the traditional teacher-oriented instruction style. Reliance on such forms of traditional method of language teaching, poses doubts on whether or not CLT approach is suitable to the contexts where English is a foreign or a second language.

In China, Li's (1998) exploration of teachers' perceptions of the implementation of CLT in teaching English revealed that the teachers relied on traditional methods of language teaching due to the difficulties which, inter alia, categories were caused by teachers which included deficiency in spoken English, deficiency in strategic and sociolinguistic competence, lack of training and retraining on CLT, teachers' misconception about CLT, and little time for and expertise in material development. There were also difficulties caused by learners, which include low English proficiency, little motivation for communicative competence and resistance to class participation.

\section{b) In Africa}

Lungu (2006) compared the effectiveness of reading and writing achievement in English between Communicative Approach (CA) and traditional methods in grade 8 Zambian basic schools and noted that communicative approaches were better than the traditional methods in many categories of pupils' mean marks achievement. He noted that communicative approaches were better than the traditional methods. Thus, this study provides us with a proof that Communicative Approach is an effective approach of language teaching and learning over traditional methods in the African context when it is utilized and implemented effectively.

Likewise, Borti (2015) explored the challenges in African classrooms using the Ghanaian context, focussing on the use of the appropriate language teaching methodology in African classrooms. In this study, experimental and control groups with a total of 86 students from an elementary school in Ghana-Tema Municipal Assembly Junior High School in Nmai Djor- Accra were used. The experimental group was taught using CLT while the control group used the structural approach. The findings revealed that the experimental group performed better than the control group to imply that CLT improved the communicative skills and the general proficiency.

However, some studies show that CLT Approach has had little or no success. A study by Moyo (2009) indicates that English as a Home Language (EHL) classroom do not use a diverse range of activity types despite the language curriculum being based on CLT approach. Classrooms are characterized by dominance of lecture or telling style of teaching and listening to the teacher being a predominant activity in EHL settings. English is used extensively but no any prohibition or discouragement on the use of the mother tongue. These teaching and learning behaviours, according to Moyo (ibid) indicate the limited application of CLT approach, hence posing questions and scepticisms on the complicated nature of CLT approach for ESL and FL contexts. A recommendation from Moyo (ibid) is that CLT approach should be revisited for its suitability in multi-level language classrooms.

Al-Magid (2006), on the other hand, assessed the effect of teachers' attitudes on the effective implementation of the Communicative Approach in ESL classrooms in Harare, Zimbabwe. Using a descriptive case study, 38 o-level secondary school English teachers from six schools were assessed in terms of their attitudes on their classroom practices. The findings indicated that the effective implementation of the Communicative Approach was critically dependent on teachers' positive attitudes towards the approach in the five categories covered by the study. Positive attitudes towards the approach reflected proper and effective implementation of CLT on the ground, but the opposite reflected improper and ineffective implementation of the approach. Therefore, the author recommends that if the Communicative Approach is to be effectively implemented in Zimbabwe, then teachers' attitudes towards it have to be improved. 
Tanzanian EFL Teachers' Perceptions and Attitudes towards Communicative Language Teaching (CLT): A Case Study of Secondary Schools in Morogoro Municipality, Tanzania

Also in Zimbabwe, Nyota and Mareva (2011) investigated the teaching of English as a Second Language (ESL) using Masvingo urban and peri-urban secondary schools as a case study. It was established that the structural approach and its associated methods and techniques were mainly used in the teaching of ESL despite the fact that CLT is recommended by the Zimbabwe School Examination Council (ZIMSEC). The study reported that CLT played a second role to structural approach and its associated methods and techniques in teaching English language at the sampled Masvingo urban and peri-urban secondary schools. The probable reasons given for such reliance on structural approach and minimal utilization of CLT, according to the authors, are either due to ignorance on the part of teachers of the principles and advantages of CLT, or due to a result of conservatism.

In Zambia, Chipili (2012) investigated the use of short stories for CLT in senior ESL classes with an aimed to design materials prepared around a short story book and testing them to determine their effectiveness in realizing syllabus objectives. The findings indicated that designed materials are a pedagogically informed decision to exploit the benefits of literature based language teaching in promoting the acquisition of ESL skills. The author is of the view that teachers need to refocus their negative perceptions regarding the use of other resources other than the prescribed course books in ESL and the practical implementation of communicative language teaching with its benefits in developing language skills.

In his comparison of the Lesotho Form E (English) and South African Grade 12 FAL (English) curricula on how CLT is realized in these two curricula, Kobo (2013) observed that the two curricula operated under the principles of CLT. He asserts that both curricula constitute communicative competence that is central to CLT. The study also revealed that the two examined English curriculum documents encouraged learners' development of lifelong skills including the ability to communicate clearly, accurately and effectively. Similarly, as it was reiterated by Mdukula (2012), Tanzania English language curriculum is based on CLT. However, since English language curriculum used in Lesotho is internationally developed to reflect countries where English is spoken as a home language and does not reflect the respective local context, Kobo (2013) is sceptical of its effective implementation. Therefore, he suggests that Lesotho education authorities should look at the curriculum and consider the inclusion of local texts, situations, and context for a proper implementation of CLT approach.

\section{c) In East Africa}

In Kenya, Onchera (2013) explored the factors perceived by teachers of English that affect the teaching of oral communication in the secondary school English language classroom. The study employed a descriptive survey design focusing on the secondary school teachers of English and their learners. The results revealed that most teachers used lecture and Question/Answer methods more than any other techniques. According to the author, the teacher played an active role while the learners remained passive. The author maintained also that teachers did not make efforts to provide opportunities for learners to practise oral skills in the class as a result learners were unable to demonstrate oral skills.

Also in Kenya, Maryslessor et al. (2012) explored the challenges teachers faced in the uses of CLT approach in the listening and speaking lessons in Lugari District. A total of fourteen teachers were involved selected from twelve secondary schools through stratified and simple random sampling technique. The study revealed that the major challenge was time and wide syllabus. According to the authors, this challenge, together with the large classes, limited the teachers' ability to involve learners in meaningful participatory activities. It was further noted that the pressure for formal examinations made teachers concentrate on training and drilling learners on how to pass the exams at the expense of communicative competence. Teachers chose to teach the learners how to pass exams and not how to use English in different situations.

\section{d) In Tanzania}

In Tanzania, studies on the implementation of CLT indicate that there are number of challenges which affect the effective implementation of this new approach. Kipacha (1993), for example, examined the extent to which CLT approach is employed in A-level English teaching in high schools in Tanzania and noted that there were difficulties in using authentic materials in communicative classroom 
Tanzanian EFL Teachers' Perceptions and Attitudes towards Communicative Language Teaching (CLT): A Case Study of Secondary Schools in Morogoro Municipality, Tanzania

because most of schools had no such facilities as radio cassettes, photocopying facilities or overhead projectors. He further found out that there were no funds for such particular intention of implementing CLT. He then concluded that teachers regard communicative approach as "a time-consumer's approach" which hinders teachers from preparing learners to pass their final examinations.

Mahenge (2012) investigated teachers' perceptions towards CLT in Dodoma Region secondary schools. The findings revealed that most of the teachers were aware of the CLT approach but the majority did not feel comfortable when they used CLT in the classroom due to student's low level of communicative competence as it is claimed that most of the students who join secondary schools have low proficiency in English. Also, the findings revealed that students did not like communicative activities because of their low level of communicative competence. Large class sizes and absence of authentic teaching and learning materials were also some of the problems that hinder implementation of CLT approach in the secondary schools in Dodoma region.

In her study on the CLT strategies in teaching English in a Tanzanian secondary school, Laiser (2013) investigated how teachers of English in Tanzanian secondary schools were using various strategies to help learners develop communicative competence in English. He noted that the teaching of English in Tanzania is encumbered by many challenges that impede the use of more effective strategies in developing language competence. Such challenges included learners' language background, inadequate teaching and learning resources and teachers' lack of knowledge and skills in using CLT methodology coupled with poor teacher training. The study also revealed that, although teachers endeavored to use a very minimal variety of English teaching strategies, there was a need to improve the way these strategies should be employed so as to develop communicative competence in learners. Laiser (ibid) recommends that teachers of English should employ more interactive CLT strategies that can enhance communicative competence in learners.

\section{The CURRENT Study}

\subsection{The Problem}

Existing literature shown above reveals that the challenges of teaching of English using CLT approach in most countries including Tanzania where English is either foreign or second language have been always similar. Unlike other countries, the findings from literature in the context of English teaching in Tanzania do not indicate explicitly the attitudes towards CLT. The study by Mahenge (2012) on the investigation of the teachers' perceptions of CLT does not link appropriately how the teachers' perceptions of CLT affect their English language teaching behaviours in classrooms. The current study, therefore, sought to fill that gap by examining the influence of Tanzanian EFL teachers' perceptions and attitudes towards implementation of CLT approach.

\subsection{Materials and Methods}

The study took place in Morogoro Municipality. The study was thus a case study in design. Five secondary schools were involved from among whom ten (10) EFL teachers were purposively selected. The level of education of the sampled English language teachers was such that out of ten (10) (100\%) teachers $9(90 \%)$ were degree holders and $1(10 \%)$ had post graduate Diploma. None had Diploma or Master's degree holders. Most of the respondents involved in this study (80\%) were Olevel teachers; only two teachers $(20 \%)$ were noted to be A-level secondary school teachers. As for sex of the respondents, male teachers represented $40 \%$ of the sample whereas female represented $60 \%$.

The data were gathered through attitudinal questionnaire of the close-ended type to find out the teachers' perceptions of the meaning, principles and characteristic features of CLT approach. It also covered procedures and techniques of classroom language teaching in CLT approach.

Using both qualitative and quantitative methods, the data were analyzed, interpreted, summarized and presented to generate themes. The data were handled qualitatively with few aspects of quantitative approach to simplify the interpretation of the findings. The findings were presented in tables representing numerical figures in quantity and percentages. Validation of data was achieved through cross-checking the authenticity of some data. The researchers counter checked all the findings from one source to the other on issues that were related. 
Tanzanian EFL Teachers' Perceptions and Attitudes towards Communicative Language Teaching (CLT): A Case Study of Secondary Schools in Morogoro Municipality, Tanzania

\subsection{The Findings}

The respondents were served with attitudinal questionnaire, in which a list of positive and negative assertions were listed towards CLT on five basic tenets of CLT i.e. pair and group work activities, teaching and learning instruction, error correction, the role of the teacher and the learner, and the instructional materials. The respondents to be rated between 'Agree', 'Strongly Agree', 'Disagree', and 'Strongly Disagree'. The responses between "Agree" and "Strongly Agree" meant 'agree' subsume favourable or positive attitudes towards the approach and the responses between "Disagree" and "Strongly Disagree" collectively meant 'disagree" to imply unfavourable or negative attitudes.

\subsubsection{Attitude towards with Pair and Group-Work Activities}

Table1. Teachers' Concurrence with Pair and Group-work Activities

\begin{tabular}{|c|c|c|c|c|}
\hline CLT Activities & Agree & $\begin{array}{l}\text { Strongly } \\
\text { Agree }\end{array}$ & Disagree & $\begin{array}{l}\text { Strongly } \\
\text { Disagree }\end{array}$ \\
\hline $\begin{array}{l}1 \text { Group work activities provide adequate opportunities for } \\
\text { developing genuine interaction among learners }\end{array}$ & $2(20 \%)$ & $8(80 \%)$ & 0 & 0 \\
\hline 2 Group work activities waste teachers' and learners' time & $2(20 \%)$ & 0 & $6(60 \%)$ & $2(20 \%)$ \\
\hline $\begin{array}{l}3 \text { Pair and group-work activities help learners to focus } \\
\text { purposefully and cooperatively on understanding spoken } \\
\text { and written text }\end{array}$ & $4(40 \%)$ & $6(60 \%)$ & 0 & 0 \\
\hline
\end{tabular}

In table 1 above, three assertions on pair and group-work activities were presented to the respondents to find out their attitudes to the concept of pair and group-work activities in CLT. The assertions number $1 \& 3$ were positive towards CLT unlike number 2 which was negative towards CLT. As indicated in Table 4.5, 100\% of respondents agreed with assertions number 1 and 3 which indicated anonymous positive attitudes towards pair and group-work activities and CLT in general. As for assertion number $2,80 \%$ of the respondents disagreed with it which also indicates that they have a positive attitude towards CLT.

\subsubsection{Attitude towards Teaching Instructions}

The second aspect that was explored to learn the EFL teachers' attitudes towards CLT was on teaching and learning instructions. Table 2 below represents the teachers' reactions to the attitudinal questionnaire on teaching and learning instructions in CLT.

Table2. Teachers' Response to the Attitudinal Questionnaire on Teaching Instructions

\begin{tabular}{|c|c|c|c|c|c|}
\hline & CLT Instruction & Agree & $\begin{array}{l}\text { Strongly } \\
\text { Agree }\end{array}$ & Disagree & $\begin{array}{l}\text { Strongly } \\
\text { Disagree }\end{array}$ \\
\hline 4 & $\begin{array}{l}\text { Fluency can be developed by teaching forms as } \\
\text { separate items }\end{array}$ & $3(30 \%)$ & $1(10 \%)$ & $4(40 \%)$ & $2(20 \%)$ \\
\hline 5 & $\begin{array}{l}\text { Focusing on selected English forms helps to develop } \\
\text { learners communication competence }\end{array}$ & $5(50 \%)$ & $3(30 \%)$ & 0 & 0 \\
\hline 6 & $\begin{array}{l}\text { English is learnt effectively when used as a vehicle } \\
\text { for teaching forms of target language }\end{array}$ & $3(30 \%)$ & $2(20 \%)$ & $4(40 \%)$ & $1(10 \%)$ \\
\hline 7 & $\begin{array}{l}\text { English is learnt effectively when used as a vehicle } \\
\text { for doing something }\end{array}$ & $3(30 \%)$ & $4(40 \%)$ & $3(30 \%)$ & 0 \\
\hline
\end{tabular}

Table 2 above indicates that all the assertions from number 4-7 focused on traditional methods of language teaching and learning except number 7 which is on CLT. The purpose was to compare the teachers' reactions between the assertions which were based on traditional teaching and those which were based on CLT approach. The table indicates that $60 \%$ of respondents disagreed with assertion number 4 to imply that they had positive attitude to the new approach which insists on the argument fluency can be developed when forms are not taught as separate entities.

However, negative attitude to CLT was shown to CLT with regard to number 5 with $80 \%$ of respondents concurring with the assertion. This means that teachers felt their learners' communication competence can be developed by focusing on selected English forms. In item 6, the respondents were 
divided with 50\% concurring with the assertion indicating their negative attitude towards the approach and thus they were in favour of the traditional teaching perspective. However, the other half disagreed with it and showed their positive attitudes by knowing that CLT intends to enable learners to use the language when performing something. Since assertion number 7 was based on positive attribute to CLT, $70 \%$ of the respondents who agreed with the assertion indicated their positive attitudes, whereas only $30 \%$ indicated negative attitudes.

Generally, the findings in table 2 above imply that the respondents had positive attitude to CLT as the majority of teachers' responses indicated favourable attitude to the CLT approach with the exception of assertion number 5 which indicated negative attitude towards CLT since the respondents were in favour of teaching instructions focused on, for example; grammar, syntax, and spelling to develop communicative competence which is contrary to the CLT approach. The respondents were divided as per assertion number 6 with one half being negative and the other half indicating their positive attitudes to CLT approach by rejecting any forms of traditional English language teaching.

\subsubsection{Attitude towards Error Correction}

The third aspect that was explored to learn the EFL teachers' attitudes towards CLT was the concept of error correction. Table 3 below represents the teachers' reactions to the attitudinal questionnaire on assertions which focused on the concept of error correction in CLT.

Table3. Teachers' Response to the Attitudinal Questionnaire on Error Correction

\begin{tabular}{|c|c|c|c|c|c|}
\hline & Error Correction Attitude & Agree & $\begin{array}{l}\text { Strongly } \\
\text { Agree }\end{array}$ & Disagree & $\begin{array}{l}\text { Strongly } \\
\text { Disagree }\end{array}$ \\
\hline 8 & $\begin{array}{l}\text { Correcting all learners' errors out of contexts can lead to } \\
\text { effective learning of English }\end{array}$ & $2(20 \%)$ & $1(10 \%)$ & $6(60 \%)$ & $1(10 \%)$ \\
\hline 9 & $\begin{array}{l}\text { Errors are seen as a natural part of the learning process, so } \\
\text { less correction helps to focus on the meaning negotiation } \\
\text { in English }\end{array}$ & $3(30 \%)$ & $4(40 \%)$ & $2(20 \%)$ & $1(10 \%)$ \\
\hline 10 & $\begin{array}{l}\text { Teacher's feedback to correct learners' errors must focus } \\
\text { on developing the meanings of English (i.e. suitable to } \\
\text { social contexts and situations) and the correct usage of } \\
\text { English }\end{array}$ & $7(70 \%)$ & $3(30 \%)$ & 0 & 0 \\
\hline 11 & $\begin{array}{l}\text { Error correction should be done immediately it should not } \\
\text { be tolerated }\end{array}$ & $5(50 \%)$ & $1(10 \%)$ & $4(40 \%)$ & 0 \\
\hline
\end{tabular}

Table 3 above presents four assertions on the concept of error correction to explore the teachers' attitudes towards CLT. The assertions on items 8 and 11 were not favourable statements to CLT. Thus, responses which concurred with the assertions implied negative attitudes towards CLT. However, items 9 and 10 were favourable assertions to CLT as the acceptance of which therefore implied positive attitude towards the approach.

The findings in 3 above indicate that the assertion on item 8 was disagreed with by $70 \%$ of the respondents to imply that teachers had positive attitude towards CLT as their disagreement to the statement the teachers felt that correcting all learners' errors out of contexts cannot lead to effective learning of English. Additionally, items 9 and 10 were concurred with by $70 \%$ and 100\%, respectively, to indicate the teachers' positive attitude to the approach as the two statements were true statements as far as the concept of error correction in CLT is concerned. Despite the teachers having shown consistent positive attitudes towards CLT, their responses on item 11 were in contrast with their fore position. The teachers' response to item 11 implied that teachers think it is better to correct all learners' errors immediately to being tolerant, unlike what CLT approach suggests.

\subsubsection{Attitude Towards Role of Teacher and Learners}

The fourth aspect that sought to probe the teachers' attitudes towards CLT was on the role of the teacher and the learner in a communicative classroom. Table 4 below represents the teachers' reactions to the attitudinal questionnaire on the role of the teacher and the learner in language teaching and learning. 
Tanzanian EFL Teachers' Perceptions and Attitudes towards Communicative Language Teaching (CLT): A Case Study of Secondary Schools in Morogoro Municipality, Tanzania

Table4. Teachers' Response on the Role of Teacher and Learner in Language T/L

\begin{tabular}{|c|c|c|c|c|c|}
\hline & Role of a Teacher & Agree & $\begin{array}{l}\text { Strongly } \\
\text { Agree }\end{array}$ & Disagree & $\begin{array}{l}\text { Strongly } \\
\text { Disagree }\end{array}$ \\
\hline 12 & $\begin{array}{l}\text { A teacher should be recognized as the sole } \\
\text { authority in the classroom: He/she should dominate } \\
\text { all situations. }\end{array}$ & 0 & 0 & $6(60 \%)$ & $4(40 \%)$ \\
\hline 13 & $\begin{array}{l}\text { A teacher should not be recognized as the sole } \\
\text { authority in the classroom: a learner should } \\
\text { dominate all situations. }\end{array}$ & $4(40 \%)$ & $6(60 \%)$ & 0 & 0 \\
\hline
\end{tabular}

To explore teachers' attitudes on the role of teacher and learner in language teaching and learning, two assertions were presented to respondents to be responded from either agree or disagree. The results were as indicated in table 4 above. Item 12 which was solely on the perspective of traditional methods of language teaching and learning was disagreed with by $100 \%$ to imply that teachers had positive attitude towards CLT. The item 13 which was an assertion under the perspective of CLT approach was agreed with by $100 \%$ also to imply that teachers had positive attitudes to CLT.

\subsubsection{Attitude towards Teaching and Learning Materials}

The fifth element to be considered on exploring the attitudes of teachers towards CLT was on learning and instructional materials. EFL teachers had the following reactions on the attitudinal questionnaire towards CLT to the assertions on learning and instructional materials. Table 5 below summarizes the teachers' responses.

Table5. Teachers' Response on Teaching and Learning Materials

\begin{tabular}{|c|c|c|c|c|c|}
\hline & Learning Materials Characteristics & Agree & $\begin{array}{l}\text { Strongly } \\
\text { Agree }\end{array}$ & Disagree & $\begin{array}{l}\text { Strongly } \\
\text { Disagree }\end{array}$ \\
\hline 14 & $\begin{array}{l}\text { Materials provided as learning material should be well } \\
\text { organized and logical }\end{array}$ & $6(60 \%)$ & $4(40 \%)$ & 0 & 0 \\
\hline 15 & $\begin{array}{l}\text { Materials provided as learning material should not } \\
\text { concentrate on de-contextualized sentences rather than } \\
\text { the logical of the argument in the relevant subject } \\
\text { matter. }\end{array}$ & $7(70 \%)$ & $2(20 \%)$ & $1(10 \%)$ & 0 \\
\hline
\end{tabular}

Both assertions in table 5 were favourable statements towards CLT. The responses to the two assertions indicated that each of the assertions $14 \& 15$ were rated as true statements by $100 \%$ and $90 \%$, respectively. These responses implied that the teachers had positive attitude towards learning and instructional materials. Since the assertions were reflective of CLT materials, such responses from the respondents suggested that the teachers had positive attitudes towards CLT approach.

The data under this section reveals that the influence of the teachers' level of education, experience, class size and the number of periods have no serious negative impact on the implementation of CLT. However, the teachers' revealed misconceptions, negative perceptions and attitudes towards CLT have likelihood serious impact on poor and ineffective implementation of the approach. The next section examines the teaching and learning activities reported in the questionnaire, interview and documentary review if they are really performed in classrooms.

\section{Conclusions}

The study investigated the EFL Teachers' Perceptions and Attitudes towards Communicative Language Teaching using Secondary School Teachers in Morogoro Municipality as a case study. We found out that over $70 \%$ of sampled EFL teachers had positive attitudes and perceptions towards CLT. It was further found that in most cases, teachers' preferred teaching procedures and techniques were completely not or minimally reflected in the procedures and techniques which operate the CLT approach.

Based on consistent information gathered through the research instruments used for this study, we can conclude that despite the fact that majority of Tanzanian EFL teachers have positive perceptions and attitudes towards CLT, their perceptions and attitudes are not reflected as their classroom teaching behaviours during actual classroom language teaching and learning. Such attitudes may be attributed to lack of encouragement and training opportunities for in-service teachers to update them with the CLT approach. 
Tanzanian EFL Teachers' Perceptions and Attitudes towards Communicative Language Teaching (CLT): A Case Study of Secondary Schools in Morogoro Municipality, Tanzania

\section{RECOMMENDATIONS}

In the light of the above findings and conclusion made, the following are the recommendations for active implementation of CLT approach in the Tanzanian context:

a) The findings showed that EFL teachers have positive attitudes towards CLT but such attitudes are not reflected on the ground to implement CLT approach. Therefore, there is a need to re-address the preparation of teachers to see and propose the best way of utilizing the many teaching techniques and procedures of FL that operate CLT.

b) The government should provide enough teaching and learning materials such as textbooks that reflect CLT and to make sure that teachers are provided with in-service training like seminars and training that will make them conversant with the methods, techniques and procedures of implementing CLT approach.

\section{REFERENCES}

[1] Al-Magid, M. A. (2006). The Effect of Teachers' Attitudes on the Effective Implementation of the Communicative Approach in ESL Classrooms; MA Dissertation, University of South Africa.

[2] Ansarey, D. (2012). Communicative Language Teaching in EFL Context: Teachers' Attitude and Perceptions in Bangladesh: ASA University review, 6 (1), 24-32.

[3] Chipili, D. (2012). The Use of Short Stories for CLT in Senior ESL Classes in Zambia; MA Dissertation, University of South Africa.

[4] Domician, I. (2008). A Study of the Implementation of the 2005 English Curriculum: A Case of Resourced and Better Resourced Secondary Schools in Dar es Salaam and Dodoma Regions. M.A Linguistics Dissertation, University of Dar es Salaam

[5] Kipacha, A. H. (1993). The Extent to which the Communicative Approach is Employed in the A-level English Teaching in High Schools in Tanzania: MA Linguistics Dissertation, UDSM.

[6] Kobo, J. M. (2013). Communicative Language Teaching: A Comparison of the Lesotho Form E (English) and South African Grade 12 FAL (English) Curricular: M.A. Education Dissertation: Stellenbosch University.

[7] Li, D. (1998). "It's always more difficult than you plan and imagine": Teachers' Perceived Difficulties in Introducing the Communicative Approach in South Korea. TESOL Quarterly, 32 (4), 677-703.

[8] Lungu, E.C. (2006). The Effectiveness of Communicative Approaches and Traditional Methods on Reading and Writing Achievement in English in Grade Eight in Selected Zambian Basic Schools: PhD Thesis, University of Zambia

[9] Mahenge, C. A. (2011). Teachers' Perceptions towards CLT Teachers' Perceptions towards Communicati ve Language Teaching (CLT): A Study of Dodoma Region Secondary Schools: MA Dissert ation: University of Dodoma

[10] Maryslessor, A. O, Barasa P.L, and Omulando, C.A. (2014). Challenges Teachers Face

[11] in the Use of the Communicative Language Teaching Approach in the Teaching Listening and Speaking Lessons in Lugrari District, Kenya; International Journal of Science and Research (IJSR), $3(9), 23-64$

[12] McClintock, K. (2012). Korean University Students' Perceptions of Communicative Language Teaching: MA Dissertation: Korea University

[13] Mdukula, P.C. (2013). Assessment the Compatibility of Competence-Based Curriculum and Material in Tanzania: A Case of Kinondon Municipality: MA Dissertation Linguistics: University of Dar es Salaam.

[14] Mohamed, H. I. (2006). Academic Writing as Social Practice: A Critical Discourse Analysis of Student Writing in Higher Education in Tanzania. Unpublished Doctoral Thesis: University of the Western Cape South Africa.

[15] Moyo, J. (2009). A Study of the Teaching/Learning of English as a First Language in a Predominantly Non-Native English Classroom in South Africa; MA Dissertation, University of Johannesburg.

[16] Msuya E. (2011). Communication Skills Course Relevance and Effectiveness at the University of Dar es Salaam, Unpublished Doctoral Thesis, University of Dar es Salaam.

[17] Nunan, D. (2004). Task Based Language Teaching, Cambridge Language Teaching: New York: Cambridge University Press. 
Tanzanian EFL Teachers' Perceptions and Attitudes towards Communicative Language Teaching (CLT): A Case Study of Secondary Schools in Morogoro Municipality, Tanzania

[18] Nyota, S. and Mareva, R. (2011). Structural or Communicative Approach: A Case Study of English Language Teaching in Masvingo Urban and Peri-urban Secondary Schools: Internal Journal of English online http://www.academicjournals.org/Ijel accessed on 16/07/2015

[19] Onchera, P.O. (2013). The Pedagogical Hindrances to Oral Communication Skills in English in Kenya: A Case of Secondary Schools in Kisii County; Online Journal of Educational Research, 4(7), 536-542.

[20] Savignon, S. (2002). Interpreting Communicative Language Teaching: Contexts and Concerns in Teacher Education: USA, Yale University Press.

\section{AUTHORS' BIOGRAPHY:}

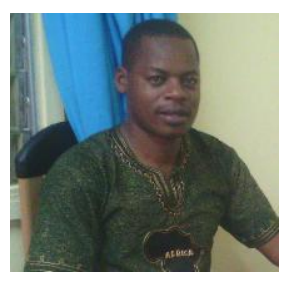

Emmanuel S. Ndulila is a holder of a Master's Degree in Linguistics from the University of Dar es Salaam. He is currently living in Dodoma with his family and works as a Communication Skills Tutor and a Dean of Students at Mineral Resources Institute-Dodoma. He also works as an Assistant Lecturer at the University of Dodoma teaching two courses-Teaching Methodology, and Curriculum Development and Evaluation.

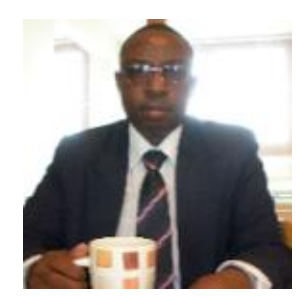

Erasmus Akiley Msuya is a Senior Lecturer in the Department of Foreign Languages and Linguistics, College of Humanities, University of Dar es Salaam. He Holds a PhD in Applied Linguistics and has Taught and researched widely in the linguistic areas of Second Language Learning and Assessment, Stylistics, Textual Analysis and Interactional Discourse. 